\title{
The Three Seas Initiative and its Economic and Geopolitical Effect on the European Union and Central and Eastern Europe
}

\author{
Grzegorz Zbińkowski iD https://orcid.org/0000-0003-4993-5547 \\ The Institute of Political Studies of the Polish Academy of Sciences, Warsaw, Poland \\ e-mail: grzegorz.zbinkowski@doktorantisppan.pl
}

\section{Abstract}

The objective of this paper is a presentation of results of an analysis of the Three Seas Initiative (TSI), whose participating countries (except Austria) treat it as a method of: a) reducing their dependence on crude oil and natural gas imports from Russia, thus increasing their energy security; b) accelerated filling of the persisting civilisation gap between the initiative participants and more developed EU countries owing to the improved quality and maturity of the transport and digital North-South infrastructure; and c) the actual implementation of the "vision of a Europe whole, free and at peace." The analysis has assumed the following research hypothesis: The CEE states' joining the EU has not markedly changed those states' development, as material differences do still exist in this respect between the new EU states and the old ones, which was verified positively.

Keywords: European Union, Three Seas Initiative, energy security, Central and Eastern European Countries, geopolitics

JEL: F02, F15, F50, O2, O57 


\section{Introduction}

While the Berlin Wall fell in $1989^{1}$, most post-communist countries were admitted to the European Union only 15 years later ${ }^{2}$ and 56 years after the launch of the Marshall Plan ${ }^{3}$. This attests to the scale of the challenges faced by those countries in terms of both economy and geopolitics. This analysis assumes the following research hypothesis: The CEE states' joining the EU has not markedly changed those states' development, as material differences do still exist in this respect between the new EU states and the old ones. The differences concern the economic potential, energy security, quality and maturity of infrastructure, which also affects the countries' geopolitical standing, as well as the cohesion and strength of the EU as a whole. The countries participating in the Three Seas Initiative (both the countries and the initiative are hereinafter referred to as the TSI-12) see the initiative as a method to fill the gap. The objective of this analysis is: an assessment of selected data (total population, land cover, GDP), the degree of energy dependence and infrastructure maturity of more developed EU member states, whether they joined the union before or after 2004; and a presentation of the TSI-12 as a method which might contribute to eliminating the development differences referred to above, including an assessment of the initiative's geopolitical implications. The objective has been achieved through:

- the identification of measures which, starting from 2014, have accompanied the implementation of the "vision of a Europe whole, free and at peace"4;

- a comparative analysis of selected data ${ }^{5}$ on the member countries of ${ }^{6}$ : the EU-28, TSI-12, not-TSI-12 EU countries (hereinafter referred to as the EU-16), including ratios and indicators describing the energy dependence of the EU-28 as a whole, as well as of the EU-16 and TSI-12 separately7;

- a comparative analysis of infrastructure competitiveness ratios for the EU-16 and TSI-12, as such ratios were published in the Global Competitiveness Report 2017-2018 by the World Economic Forum;

1 November $9^{\text {th }}, 1989$.

2 Estonia, Latvia, Lithuania, Hungary, Poland, Slovenia, Slovakia - since May $1^{\text {st }}$, 2004; Bulgaria, the Czech Republic, Romania - since January 1 ${ }^{\text {st }}, 2007$; Croatia - since July 1 ${ }^{\text {st }}, 2013$.

32017 saw the $70^{\text {th }}$ anniversary of the speech by George Marshall, US Secretary of State. The speech had a material effect on the changes in post-WW2 Europe. It was given at Harvard University on June $5^{\text {th }}, 1947$ and defined the objectives for the European Recovery Program, which were implemented over four years starting from 1948. The economies of all participating countries, except Germany, grew above their respective pre-WW2 levels. The Soviet Union and its satellite states rejected the invitation to the program.

4 The origins of the vision and references thereto will be discussed herein later.

5 Based on Eurostat database (Comext) and Eurostat estimates.

6 The analysis is limited by the lack of sufficient data which is, in most cases, available exclusively as aggregate figures for the EU-28 as a whole and individual EU-28 member states, but not for the TSI-12 and EU-16 separately. Where feasible and reasonable, the data was aggregated accordingly.

7 In this division, as dependence on Russia. 
The Three Seas Initiative and its Economic and Geopolitical Effect on the European Union...

- a presentation of the origins of the TSI-12, as well as the progress and results of the Dubrovnik, Warsaw and Bucharest Summits based on available press announcements, official documents and publications, the major part of which were prepared following Donald Trump's visit to Poland in 2017;

- an analysis of the geopolitical aspects of the TSI-12 initiative.

\section{Origins of the TSI-12}

In November 2014, the "Completing Europe, from the North-South Corridor to Energy, Transportation, and Telecommunications Union" report ${ }^{8}$ was issued.

The report starts with some words which, while difficult for Europe, should be treated as not only a challenge but also an opportunity: "Europe is at an inflection point in its history. The vision of a Europe whole, free, and at peace is under pressure from within and outside its frontiers. (...) At the same time, the EU faces multiple external threats, including a resurgent Russia." 9 The report was officially presented at a high-level meeting in Brussels on March 24 ${ }^{\text {th }}, 2015^{10}$.

The vision of a "Europe whole and free" was originally presented by President George H.W. Bush in his speech given in Mainz, Germany, on May 31 $1^{\text {st }}, 1989$, and addressed to citizens and political leaders. The President said, "And for 40 years, the world has waited for the Cold War to end. And decade after decade, time after time, the flowering human spirit withered from the chill of conflict and oppression; and again, the world waited. However, the passion for freedom cannot be denied forever. The world has waited long enough. The time is right. Let Europe be whole and free."11 The vision's objectives were aptly captured by Robert E. Hunter ${ }^{12}$ : "When President George H.W. Bush presented his vision of a 'Europe whole and free and at peace', and President Bill Clinton created the architecture to pursue that vision, two goals were uppermost: take Central Europe permanently off the geopolitical chessboard and draw

8 The joint report by the Atlantic Council and Central Europe Energy Partners in coordination with the Central \& Eastern Europe Development Institute with the support of Grupa LOTOS S.A. and Przedsiębiorstwo Eksploatacji Rurociagów Naftowych S.A., PERN Przyjaźń. The foreword was signed by Frederick Kempe, President and CEO of the Atlantic Council, Janusz Luks, CEO at the Central Europe Energy Partners and Jan Kulczyk, Chairman of the Board of Directors of Kulczyk Investments, Founder of the CEED Institute. Available at: http://www.ceep.be/www/wp-content/uploads/2015/03/Europe-needs-an-energy-highway_PR_CEEP.pdf (accessed: 6.09.2018).

9 Ibidem, p. 5

10 Participants of the meeting included Maroš Šefčovič, European Commission Vice-President for Energy Union (keynote speaker); Dominique Ristori, Director General of European Commission's DG Energy; Jerzy Buzek, Chairman of the European Parliament's ITRE Committee; Massimo Cingolani, Managerial Advisor in Operations Directorate, European Investment Bank. Paweł Olechnowicz and Jan Kulczyk represented CEEP, David Koranyi represented the Atlantic Council.

11 The official website of the U.S. Diplomatic Mission to Germany, A Europe Whole and Free. Available at: https://usa.usembassy.de/etexts/ga6-890531.htm (accessed: 9.09.2018).

12 U.S. Ambassador to NATO under President Clinton, a senior adviser at the RAND Corporation. 
Russia productively into the outside world." ${ }^{13}$ The TSI-12 vision started to take a clear shape in 2015 driven by certain events: February 19 ${ }^{\text {th }}, 2015$ marked the inauguration of Kolinda Grabar-Kitarović, put forward by the Croatian Democratic Union, as President of Croatia, and on August $6^{\text {th }}, 2015$, Andrzej Duda of the Law and Justice party was sworn in as President of Poland. Then, on the eve of the $70^{\text {th }}$ Session of the United Nations General Assembly ${ }^{14}$, on September $29^{\text {th }}, 2015^{15}$, the first meeting took place of the presidents (of Bulgaria, Croatia, Poland and Romania), Foreign Affairs Ministers (of Estonia, Latvia, Lithuania, Hungary and Slovakia), as well as lower rank officials (from Austria, the Czech Republic and Slovenia) ${ }^{\mathbf{1 6}}$ of the twelve EU member states located between three seas: the Adriatic, Baltic and Black Seas ${ }^{\mathbf{1 7}}$. At the meeting, the establishment of the TSI-12 was announced and the next meeting was convened for Dubrovnik.

\section{The EU-28 and TSI-12 - population, land cover and GDP}

The first part of the analysis of the TSI-12 is a discussion of the participating countries' potential and a comparison of analysis findings with relevant data on the EU-28. As set forth in Table 1, TSI-12 countries' percent shares in the EU-28 are as follows: $21.86 \%$ of the total population ${ }^{18}, 27.96 \%$ of land cover $^{19}$ and $10.81 \%$ of GDP ${ }^{20}$. The EU-28 total population was: in 2015 - 509.70; in 2016 - 511.28; and in 2017 - 512.57. The TSI-12 total population was: in 2015 - 112.35; in 2016 - 112.19; and in 2017 - 112.06. Over the period covered by the comparison, the total EU-28 population increased, while that of the TSI-12 decreased, which drives the following changes in the percent share of the TSI-12 in the EU-28 total population: 2015: 22.04\%, 2016: 21.94\% and 2017, as already given above: $21.86 \%{ }^{\mathbf{2 1}}$.

13 Robert E. Hunter, A 'Europe Whole and Free and at Peace', the RAND Blog, September 9th 2008. Available at: https://www.rand.org/blog/2008/09/a-europe-whole-and-free-and-at-peace.html (accessed: 9.09.2018).

14 The session commenced on September $15^{\text {th }}, 2015$.

15 See: Announcement for Tuesday, 29 September 2015, President of Croatia, Kolinda Grabar-Kitarović. Available at: http://predsjednica.hr/rezultati/\#1. [After additional inquiry about the Three Seas Initiative] (accessed: September $6^{\text {th }}$ 2018). The meeting was held at the Grand Hyatt Hotel and was also attended by the Atlantic Council's representatives.

16 The emergence of a European Project. Three Summits for the Three Seas Initiative, 'New Strategy Center, Ośrodek Studiów Wschodnich', Warsaw, 2018, p. 4. Available at https://newstrategycenter.ro/wp-content/uploads/2016/04/NSC_OSW_3SI_policy_paper.pdf (accessed: 6.09.2018).

17 TSI-12 countries in the alphabetic order: Austria, Bulgaria, Croatia, the Czech Republic, Estonia, Hungary, Latvia, Lithuania, Poland, Romania, Slovenia and Slovakia.

18 In millions.

19 In square kilometers.

20 In current prices and EURm.

21 Source: own study based on Eurostat. Data extracted on August 30 ${ }^{\text {th }}, 2018$. 
The Three Seas Initiative and its Economic and Geopolitical Effect on the European Union...

Table 1. Population, land cover and GDP of the EU-28 and TSI-12 countries $^{\mathbf{2 2}}$

\begin{tabular}{|l|c|c|c|}
\multicolumn{1}{c|}{ Country } & $\begin{array}{c}\text { Total population } \\
\text { (millions) }\end{array}$ & $\begin{array}{c}\text { Land cover } \\
\text { (square kilometre) }\end{array}$ & $\begin{array}{c}\text { GDP } \\
\text { (current prices, EURm) }\end{array}$ \\
\hline EU-28 & 512.57 & $4,369,364.00$ & $15,336,242.50$ \\
\hline Bulgaria & 7.10 & $110,995.00$ & $50,430.10$ \\
\hline Czech Republic & 10.59 & $78,874.00$ & $191,642.80$ \\
\hline Estonia & 1.32 & $45,347.00$ & $23,002.30$ \\
\hline Croatia & 4.14 & $56,539.00$ & $48,989.50$ \\
\hline Latvia & 1.94 & $65,519.00$ & $26,856.60$ \\
\hline Lithuania & 2.82 & $65,412.00$ & $41,857.00$ \\
\hline Hungary & 9.78 & $93,013.00$ & $123,494.60$ \\
\hline Austria & 8.80 & $83,944.00$ & $369,685.90$ \\
\hline Poland & 38.42 & $313,851.00$ & $465,604.90$ \\
\hline Romania & 19.64 & $239,068.00$ & $187,939.90$ \\
\hline Slovenia & 2.07 & $20,277.00$ & $43,278.10$ \\
\hline Slovakia & 5.44 & $49,026.00$ & $84,985.20$ \\
\hline TSI-12 & 112.06 & $1,221,865.00$ & $1,657,766.90$ \\
\hline TSI-12 vs EU-28[\%] & $21.86 \%$ & $27.96 \%$ & $10.81 \%$ \\
\hline
\end{tabular}

Source: own study based on Eurostat ${ }^{23}$. Data extracted on August 30th 2018.

Among the TSI-12 countries, the largest 2016/2017 population decreases in percentage terms were recorded in Lithuania $(-1.6 \%)$ and Latvia $(-1.1 \%)$. The largest increase was recorded in Austria (0.7\%), while the EU-28 average was $0.3 \%$. The EU-28 real GDP per capita ${ }^{24}$ was $^{25}$ : in 2015 - 26,700; in 2016 - 27,100; and in 2017 - 27,700. Excluding Austria, the ratios for the TSI-12 countries were lower than for the EU-28. For Poland, they were: 2015 - 10,900; 2016 - 11,200; 2017 - 11,800.

\section{EU-28/EU-16 and TSI-12 energy dependence (crude oil and natural gas)}

The energy dependence of the EU and its member states is of the utmost importance, as it enables energy carrier suppliers to exert pressure on those states. It was, for instance, evidenced by the Ukraine-Russian Federation gas crisis, when in the first week of 2009 the dispute brought about drops in gas pressure. This induced some CEE states

22 Total population and GDP - data for 2017; land cover - data for 2015.

23 All Eurostat data was derived from the official Eurostat database. Available at: https://ec.europa. eu/eurostat/data/database (accessed: 6.09.2018).

24 In euro.

25 Aggregated data for the EU-28 published by Eurostat is not the arithmetic mean of the real GDP per capita for all EU-28 member states. Therefore, the methodological consistency of the analysis renders it impossible to correctly calculate the real GDP per capita for the TSI-12 and compare the result thus obtained with Eurostat's data for the EU-28. 
to make decisions to increase the capacity of gas storage facilities and gas interconnectors, and to enable reverse flow, that is, two-way gas pumping. This accelerated the implementation of 'North-South Corridor' initiatives, including LNG terminals in Świnoujście, Poland, and the Croatian Island of Krk.

Eurostat's data ${ }^{26}$ shows that with respect to crude oil, the EU-28's energy dependence rose from $83.4 \%$ to $87.8 \%$ between 2007 and 2016 . The dependence on gas supplies increased from $59.5 \%$ to $70.4 \%$ over the same period.

In 2017, the suppliers for crude oil were ${ }^{27}$ Russia (30.0\%), Norway (13.0\%), Kazakhstan (7.9\%), Iraq (6.9\%), Nigeria (6.5\%), Saudi Arabia (5.7\%), other suppliers ${ }^{28}(30.1 \%)$; and for gas, they were Russia (37.0\%), Norway (37.0\%), Algeria (12.7\%), Qatar (5.6\%) and other suppliers ${ }^{29}(7.7 \%)$.

The data reveals that in 2017, Russia was the largest crude oil supplier to the EU-28, and together with Norway was one of the two largest gas suppliers with equal shares. Thus, it appears to be of key importance to present the dependence of the EU-16 and TSI-12 on crude oil and natural gas supplies from Russia.

The findings of the analysis of the Eurostat data ${ }^{30}$ are as follows: Figure 1 reveals that in the case of crude oil in 2017: a) $68.75 \%$ of the EU-16 states fall in the $0-25 \%$ dependency range, $18.75 \%$ of them in the range $25-50 \%, 6.25 \%$ in the range $50-75 \%$ and $6.25 \%$ in the range $75-100 \%$; b) $33.33 \%$ of TSI- 12 states fall in the $0-25 \%$ dependency range, $8.33 \%$ of them in the range $25-50 \%, 33.33 \%$ in the range $50-75 \%$ and $25 \%$ in the range $75-100 \%$. The analysis shows that the EU-16 states are significantly less dependent on supplies of crude oil from Russia than the TSI-12 states are.

Figure 2 illustrates the following figures concerning the dependence on natural gas supplies in 2017: a) $68.75 \%$ of the EU-16 states fall in the $0-25 \%$ dependency range, $12.50 \%$ of them in the range $25-50 \%, 12.50 \%$ in the range $50-75 \%$ and $6.25 \%$ in the range $75-100 \%$; b) $8.33 \%$ of the TSI-12 states fall in the $0-25 \%$ dependency range, $0 \%$ (none) of them in the range $25-50 \%, 16.67 \%$ in the range $50-75 \%$ and $75 \%$ in the range $75-100 \%$. Again, the analysis shows that the EU-16 states are significantly less dependent on supplies of gas from Russia than the TSI-12 states are, and also that TSI-12 states' dependence is very large. Thus, the measures taken by the TSI-12 with a view to diversifying gas supplies are justified.

26 EU-28 energy dependence - total oil and gas as percent share of imports in total energy carrier consumption. According to Eurostat: the indicator shows the share of total inland energy needs met by imports from other countries.

27 Extra-EU imports of crude oil/natural gas, main trading partners' shares in total value.

28 Not specified by Eurostat.

29 Ibidem.

30 See Eurostat data. Available at: https://ec.europa.eu/eurostat/statistics-explained/index.php?title=File:Share_(\%25)_of_Russia_in_national_extra-.EU_imports_of_each_Member_State,_2017, in_value_updated.png (accessed: 30.09.2018) 
The Three Seas Initiative and its Economic and Geopolitical Effect on the European Union...

EU-16 - TSI-12

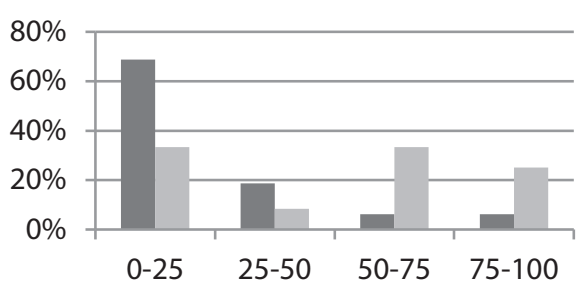

Figure 1. Crude oil - Russia's percentage share in the value of national extra-EU imports of Member States, 2017. Four dependency ranges are chosen. $\square \mathrm{EU}-16 \quad$ TSI-12

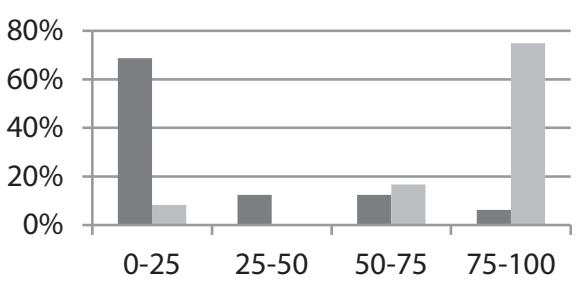

Figure 2. Natural gas - Russia's percentage share in the value of national extra-EU imports of Member States, 2017. Four dependency ranges are chosen

\section{EU-16/TSI-12 infrastructure competitiveness}

Given that the TSI-12 states ${ }^{31}$ were previously the Soviet Union's CEE satellite states, their infrastructure is poorer than the infrastructure developed post-WW2 in Western Europe. Infrastructure projects are, by their very nature, capital- and time-consuming as aptly described in the Atlantic Council and PwC's 2017 report ${ }^{32}$ : "Central and Eastern Europe (CEE) has made unprecedented progress after decades of underinvestment ... But the gap is still significant - a citizen of the 'old EU' has on average twice as many kilometers of motorways to drive on than his/her counterpart in CEE." The scale of capital expenditure needs is shown by the following remark: "Almost EUR 210 billion has been spent on transport infrastructure in CEE EU member states over the past 20 years... Five key TEN-T corridors play a paramount role for the Three Seas region (North Sea-Baltic, Baltic-Adriatic, Rhine Danube, Orient/East-Med and Mediterranean) - more than EUR 384 billion across over 2,000 projects is still needed to complete them." For this analysis, the comparison of the EU-16 infrastructure with the TSI-12 infrastructure was based on data prepared by the World Economic Forum and included in the Global Competitiveness Report 2017-2018 ${ }^{33}$.

Figure 3 shows that in each category covered by the comparison, the quality of EU-16 infrastructure is better than that of TSI-12 infrastructure. It shows that for the EU-16, individual infrastructure types are rated as follows: electricity supply -6.28 , air transport -5.65 , ports -5.35 , roads -5.16 , railroads -4.86 and overall infrastructure -5.56 .

31 Except Austria.

32 Joint Atlantic Council-PwC Report A Road Ahead - CEE Transport Infrastructure Dynamics, 2017. Available at: https://www.pwc.com/gx/en/utilities/publications/assets/pwc-the-road-ahead.pdf (accessed: 9.09.2018).

33 See: Global Competitiveness Report 2017-2018, The World Economic Forum. Available at: http://reports.weforum.org/global-competitiveness-index-2017-2018/downloads/ (accessed: 9.09.2018). 
Meanwhile, for the TSI-12, the respective ratings are as follows: electricity supply -5.71 , air transport -4.51 , roads -4.22 , ports -4.21 , railroads -3.78 , overall infrastructure -4.60 . The findings of the analysis corroborate the statement that, apart from diversifying the supply sources of energy carriers, one of the TSI-12's top priorities is investment projects providing for the development of necessary infrastructure (including power infrastructure). Given the volume limitations to which this paper is subject, this study omits the TSI-12's third priority, digital communication.

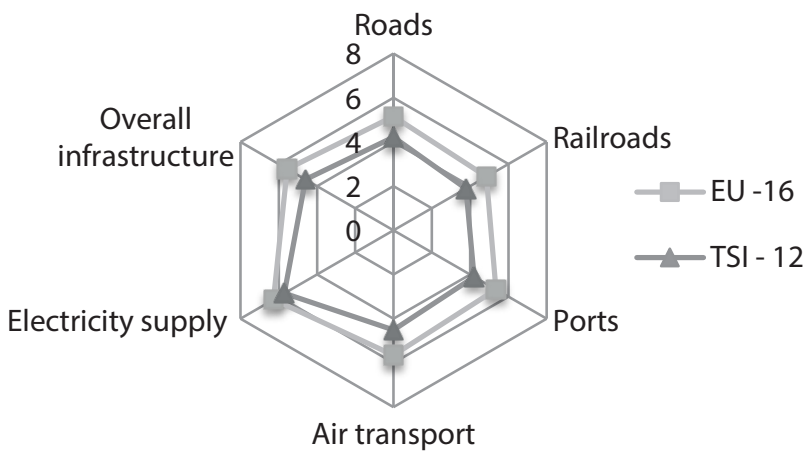

Figure 3. Quality of EU-16 vs. TSI-12 infrastructure ${ }^{34}$

Source: own study based on Global Competitiveness Report 2017-2018.

\section{Arrangements of individual TSI Summits}

\section{Dubrovnik Forum 2016}

As agreed at the Grand Hyatt Hotel in 2015, and on August $25^{\text {th }}$ and $26^{\text {th }} 2016$ in Dubrovnik, Croatia, the "Strengthening Europe by Connecting North and South" Forum was held, attended by representatives of the TS-12 states, as well as the USA, China and Turkey ${ }^{35}$. The first day of the event concluded with the TSI-12 representa-

34 According to the notes to the Report: "Rating based on a survey by the World Economic Forum, using a scale from 1 (extremely underdeveloped) to 7 (extensive and efficient). EU value is calculated as a simple average".

35 Kolinda Grabar-Kitarović, President of Croatia; Andrzej Duda, President of Poland; Dalia Grybauskaitè, President of Lithuania; Rosen Plevneliev, President of Bulgaria; János Áder, President of Hungary; Borut Pahor, President of Slovenia; Peter Pellegrini, Deputy Prime Minister for Investments and Informatization of Slovakia; Petru Sorin Buşe, Minister of Transport of Romania; Václav Kolaja, Deputy Minister of Foreign Affairs of the Czech Republic; Michael Linhart, Deputy Minister for Foreign Affairs of Austria; Väino Reinart, Undersecretary for Economic and Development Affairs at the Ministry of Foreign Affairs of Estonia; Andris Maldups, Director of Transit Policy Department in the Ministry of Transport of Latvia; General James L. Jones, Jr., President of Jones Group International, Former U.S. National Security Advisor to President Barack Obama (at the Dubrovnik Forum, he represented the Atlantic Council); Liu Haixing, Assistant Minis- 
tives signing the Three Seas Initiative Summit's Joint Declaration, the key provisions of which are $\mathrm{ar}^{36}$.

- attention on joining CEE countries' economies and infrastructures along the North-South axis instead of the East-West one;

- expanding the existing cooperation in the areas of energy, transport, digital communication and economy sectors, which will strengthen the European Union as a whole;

- implementing the initiative without a new parallel structure, with the use of existing EU and transatlantic cooperation mechanisms;

- the TSI-12's openness to partnerships with those entities all over the world which respect the EU's values and principles;

- a statement which reads: "The Three Seas Initiative is an informal platform to strengthen the overall political, economic, infrastructure and security cooperation in the authentic Central Europe. The goal of the Initiative is to establish a framework for decisive action in garnering and securing political support for specific cross-border strategic projects of interest to the States involved."37

During his speech at the Forum, General James L. Jones, Jr. set directions for the TSI-12: "strengthening the security and resilience of northern, central, and eastern Europe - and by extension all of Europe and the transatlantic community, ... to consider developing an even bolder vision to link the European Union to the wider European space ..., the importance of the participation of the private sector in the TSI and the need for political leaders in the Three Seas Area and the EU to foster business conditions and policy clarity needed to generate private sector investment."38 It was agreed that the next TSI-12 summit would be held in June 2017 in Wrocław, Poland ${ }^{39}$.

ter of Foreign Affairs of the People's Republic of China, Secretary-General of the Secretariat for Cooperation between China and Central and Eastern European Countries; Ahmet Yıldız, Deputy Foreign Minister of Turkey.

36 See: The Joint Statement on the Three Seas Initiative (the Dubrovnik Statement). Available at: http:// predsjednica.hr/files/The\%20Joint\%20Statement\%20on\%20The\%20Three\%20Seas\%20 Initiative(1).pdf (accessed: 6.09.2018).

37 See: Introduction to Newsletter of the Office of the President of the Republic of Croatia signed by Kolinda Grabar-Kitarović, 'Views and News', No. 6, September 2016, Zagreb, Croatia, p. 3. Available at: http://predsjednica.hr/files/NEWSLETTER\%20VIEWS\%20and\%20NEWS_no\% 206.pdf (accessed: 6.09.2018).

38 See: Remarks by General James L. Jones, Jr. at the Dubrovnik Three Seas Initiative Presidential Roundtable. Available at: http://www.atlanticcouncil.org/news/transcripts/remarks-by-general-james-I -jones-jr-at-the-dubrovnik-three-seas-initiative-presidential-roundtable (accessed: 6.09.2018).

39 However, due to the US President's planned attendance at the summit, its original date and venue were changed from June to July and from Wrocław to Warsaw, respectively. 


\section{Warsaw Summit 2017}

On July $6^{\text {th }}$ and $7^{\text {th }} 2017$, in Warsaw, the Warsaw Summit was held under the banner reading: "Connectivity, commerciality, complementarity." The Forum was attended by representatives of all 12 member states, as well as the US President ${ }^{40}$. Compared with the Dubrovnik Forum 2016, four more TSI-12 states were represented by their presidents, which brought the total number of TSI-12 presidents present to ten. A major reason was undoubtedly the US President's visit to Warsaw just before the G20 Summit in Hamburg. It is worth noting that President Trump's speech at the Summit "was the first programmatic, public speech devoted to international affairs after [his inauguration] as President of the USA" (Wiśniewski 2017, p. 28). We also have to bear in mind that the TSI objectives are consistent with the US Administration's strategy for building Post-Cold War Europe, mentioned in Section 2 hereof. With respect to economic cooperation, President Trump said in Krasiński Square: "And we are committed to securing your access to alternate sources of energy, so Poland and its neighbors are never again held hostage to a single supplier of energy." ${ }^{11}$

It is an interesting conclusion that, since then, we can speak of the "American and CEE partnership" (Wiśniewski 2017, p. 28). Certain analogies here arise to the "Polish and German partnership" described in the literature, but a discussion of this issue would go beyond the scope hereof.

The key arrangements of the TSI-12 Warsaw Summit repeat those reached in Dubrovnik to a large extent. However, the Warsaw Summit declaration is approximately twice as long, and more often refers to complementarity, cohesion and support of the EU's initiatives. Moreover, it is here that, for the first time, some explicit statements are voiced which were absent from the Dubrovnik Summit declaration: "the 3 Seas Initiative has the following priorities: enhanced transportation connections of our region to develop and further integrate into the trans-European transport (TEN-T) network, implementation of the Union's Energy policy objectives, promote business character of joint economic projects, full synergy with the EU policies; Hereby agree that the 3 Seas Initiative is a useful platform that adds to an efficient and cohesive European Union. The development of cooperation among the 3 Seas states is contributing to the development of the entire European Union, which will,

40 Donald Trump, President of the United States of America, a special guest; Kolinda Grabar-Kitarović, President of Croatia; Andrzej Duda, President of Poland; Dalia Grybauskaitè, President of Lithuania; Rumen Radev, President of Bulgaria; János Áder, President of Hungary; Borut Pahor, President of Slovenia; Andrej Kiska, President of Slovakia; Klaus lohannis, President of Romania; Kersti Kaljulaid, President of Estonia; Raimonds Vējonis, President of Latvia; Jan Hamáček, Chairman of the Chamber of Deputies of the Czech Republic; Thomas M. Buchsbaum, Austrian Ambassador to Poland.

41 The official website of the Whitehouse, Remarks by President Trump to the People of Poland, issued on 6.07.2017. Available at: https://www.whitehouse.gov/briefings-statements/remarks-president-trump-people-poland/ (accessed: 9.09.2018). 
The Three Seas Initiative and its Economic and Geopolitical Effect on the European Union...

as a result, remain ambitious, united and resilient as a whole"42. It was also resolved (and included in the declaration) to enhance political meetings with the " 3 Seas Business Forum”.

\section{Bucharest Summit 2018}

As arranged in 2017, on September $17^{\text {th }}$ and $18^{\text {th }}, 2018$, the Bucharest Summit took place in the capital of Romania. The summit was attended by representatives of the 12 TSI states, as well as the EU and the USA ${ }^{43}$. In the accompanying " 3 Seas Business Forum," representatives of other countries, think tanks, chambers of commerce, economic organizations and individual companies also participated ${ }^{44}$. While the Bucharest Summit's arrangements confirm the political direction approved in Dubrovnik and Warsaw, the third summit was "focused on deliverables which will also enhance the value-added of the Initiative." 45 Accordingly, having repeated the Dubrovnik and Warsaw arrangements, the Bucharest documents firmly emphasize concrete projects, results and deliverables ${ }^{46}$. Additionally, the 3 SI Business Forum was set as a regular annual event to monitor the implementation of the shortlisted projects ${ }^{47}$. Simultaneously, the 3SI Network of the Chambers of Commerce of the TSI-12 countries was established, as was the Three Seas Investment Fund. On September 17 ${ }^{\text {th }}, 2018$, two documents were signed: the Joint Statement for the creation of the Network of the Chambers

42 See: The Second Summit of the 3 Seas Initiative Joint Declaration. Available at: http://three-seas.eu/ wp-content/uploads/2018/06/WARSAW.pdf (accessed: 11.09.2018).

43 Klaus Iohannis, President of Romania; Kolinda Grabar-Kitarović, President of Croatia; Andrzej Duda, President of Poland (for the first day of the Summit); Mateusz Morawiecki, Prime Minister of Poland (for the second day of the Summit); Dalia Grybauskaitè, President of Lithuania; Rumen Radev, President of Bulgaria; János Áder, President of Hungary; Borut Pahor, President of Slovenia; Andrej Kiska, President of Slovakia; Dr Alexander van der Bellen, Federal President of Austria; Eiki Nestor, President of Parliament of Estonia; Radek Vondráček, President of the Chamber of Deputies of the Czech Republic; Edgars Rinkēvičs, Minister of Foreign Affairs of Latvia. Special guests/partners: Jean-Claude Juncker, President of the European Commission; Rick Perry, Secretary of Energy of the United States of America; Heiko Mass, Minister for Foreign Affairs of the Federal Republic of Germany. International Financial Institutions: Sir Suma Chakrabarti, President of the European Bank for Reconstruction and Development (EBRD); Vazil Hudak, Vice President of the European Investment Bank (EIB); Mamta Murthi, Director, World Bank Group.

44 The countries and organisations represented at the Business Forum included: Georgia, Macedonia, Montenegro, Albania, Moldova, the European Commission, the Atlantic Council, and the Chambers of Commerce of the Three Seas countries. The list of participants of the Three Seas Initiative Summit and the "3 Seas Business Forum" was separately sent to the author by Gabriel-Cristian Piscociu, State Councilor, via e-mail on September $28^{\text {th }}, 2018$.

45 See: The official website of the Three Seas Initiative Bucharest Summit, Q\&A. Available at: http:// three-seas.eu/qa/ (accessed: 12.09. 2018).

46 See: The Joint Declaration of the Third Summit of the Three Seas Initiative. Available at: http:// www.presidency.ro/ro/media/comunicate-de-presa/joint-declaration-of-the-third-summit-of-the-three-seas-initiative (accessed: 26.09.2018).

47 See: The Three Seas Initiative - Priority Interconnection Projects. Available at: http://three-seas.eu/ press-releases/ (accessed: 26.09.2018). 
of Commerce of the "Three Seas Initiative"48 and the Letter of Intent in relation to the Three Seas Investment Fund. Such an approach strongly supports the implementation of the assumptions and objectives of TSI-12, as expenditure on the implementation of the initiative is an extremely material issue (Ukielski 2016, p. 37).

\section{TSI-12 geopolitical aspects}

Despite the widely declared economic nature of the TSI-12, the initiative is also said to have geopolitical objectives, which appears to reflect the facts. If the TSI-12 countries reduce their energy dependence on Russia, the latter will not be able to exert such a large influence on those countries (for instance, it will not be able to use 'gas blackmail'), which will also strengthen the entire EU. This is aptly rendered in the following statement: "while officially the Three Seas Initiative's objectives are economic, most participating states and numerous other countries see its principal objective as another strategic step towards safety: closing the ranks in the face of threats from the East" (Popescu 2017, p. 37). The TSI-12 is also referred to as a response to challenges and threats originating in Poland's international environment (Sienkiewicz 2016, p. 143). Quite naturally, the question arises regarding the TSI-12's effect on Nord Stream 2, which has already gone from concept development to implementation on both the German and Russian sides. This is perhaps the reason for Germany's reserved approach to the initiative. However, before the Bucharest Summit, Germany requested to be included in TSI-12 work as a partner state. The TSI-12 is in its entirety a project unifying and strengthening the EU, despite it being sometimes presented differently, as seen in the following statement: "It has been seen as building 'Plan B' for the EU or a project competing with Germany's initiatives” (Gniazdowski 2017, p. 79). It appears, though, that "the Berlin political circles showed concern that the Three Seas Initiative is an attempt at establishing a political block which would compete with the 'old Europe' with a view to destroying the existing system in which Germany and France have had particularly strong positions and been able to successfully play off the incoherent Central and Eastern Europe" (Orzelska-Stączek 2018, p. 161). We have to bear in mind that the EU is not the CEE states on the one side and Brussels on the other, but a union of all 28 member states; and that the EU can be strong as a whole if the TSI-12 countries are allowed to reach the level of economic development (including infrastructure) of the EU-16 countries and the structure and diversification of oil and gas supplier base of the TSI-12 is similar to that of the EU-16.

48 See: The Joint Statement for the creation of the Network of the Chambers of Commerce of the "Three Seas Initiative". Available at: http://www.presidency.ro/ro/media/comunicate-de-presa/joint-statement-for-the-creation-of-the-network-of-the-chambers-of-commerce-of-the-three-seas-initiative (accessed: 26.09.2018). 
The Three Seas Initiative and its Economic and Geopolitical Effect on the European Union...

\section{Conclusion}

This paper's research hypothesis: “The CEE states' joining the EU has not markedly changed those states' development, as material differences do still exist in this respect between the new EU states and the old ones" has been proved true. The TSI-12 does help to fill those development gaps. It is both an economic and geopolitical initiative supporting the realization of the vision of a strong Europe actually unified and thus able to be free. The current scope of individual TSI-12 countries' dependence on gas supplies from Russia hinders the implementation of this vision, as it exposes the TSI-12 countries to the risk of gas blackmail. With each subsequent TSI-12 summit (in Dubrovnik, Warsaw and Bucharest), the project objectives have become more and more detailed, and the project itself has matured from the planning phase into the implementation phase, while the initiative has drawn increasing global attention, which manifests itself in the growing profile of the guests. In terms of the policy for energy carriers, of whom the EU is a net importer, the supplier base should be enhanced so that no supplier has a dominant position. This would enable the EU to hold a good position in negotiating the prices of energy carriers. The current relations between the US and European countries economically involved in Iran are far from good, owing to new US sanctions against Iran. Nor does such a state of affairs help the "US-CEE partnership." On the other hand, the TSI-12 should first focus on implementing the initiative's internal projects, and only later consider including other non-EU-28 countries in the cooperation.

\section{References}

Announcement for Tuesday, 29 September 2015, President of Croatia, Kolinda Grabar-Kitarović. Available at: http://predsjednica.hr/rezultati/\#1 (accessed: 6.09.2018).

Global Competitiveness Report 2017-2018, The World Economic Forum. Available at: http://reports.weforum.org/global-competitiveness-index-2017-2018/downloads/ (accessed: 9.09.2018).

Gniazdowski, M. (2017), Trójmorze - nowy instrument w polskiej polityce zagranicznej [Three Seas Initiative - new tool of the Polish foreign politics] (in Polish), "Polski Przegląd Dyplomatyczny, Polski Instytut Spraw Międzynarodowych"[The Polish Diplomatic Review of the Polish Institute of International Affairs], No. 4 (71) 2017. Hunter, Robert E., A 'Europe Whole and Free and at Peace', the RAND Blog, 9.09.2008. Available at: https://www.rand.org/blog/2008/09/a-europe-whole-and-free-and-at -peace.html (accessed: 9.09.2018).

Introduction to Newsletter of the Office of the President of the Republic of Croatia signed by Kolinda Grabar-Kitarović, 'Views and News', No. 6, September 2016, Zagreb, Croatia, p. 3. Available at: http://predsjednica.hr/files/NEWSLETTER\%20 VIEWS\%20and\%20NEWS_no\%206. pdf (accessed: 6.09.2018).

Joint Atlantic Council - PwC Report Joint Atlantic Council - PwC Report "A Road Ahead - CEE Transport Infrastructure Dynamics", 2017. Available at: https://www. 
pwc.com/gx/en/utilities/ publications/assets/pwc-the-road-ahead.pdf (accessed: 9.09.2018).

Orzelska-Stączek, A. (2018), Inicjatywa Środkowoeuropejska a Trójmorze - odmienne koncepcje współpracy w Europie Środkowo-Wschodniej [The CEE initiative and the three Seas - different cooperation concepts in the CEE] (in Polish), "Studia Polityczne" [Political Studies], No. 1 (46) 2018.

Popescu, O. (2017), Trójmorze - nowy instrument $w$ polskiej polityce zagranicznej [Three Seas Initiative - new tool of the Polish foreign politics] (in Polish), "Polski Przegląd Dyplomatyczny, Polski Instytut Spraw Międzynarodowych” [The Polish Diplomatic Review of the Polish Institute of International Affairs], No. 4 (71) 2017. Remarks by General James L. Jones, Jr. at the Dubrovnik Three Seas Initiative Presidential Roundtable. Available at: http://www.atlanticcouncil.org/news/transcripts/ remarks-by-general-james-1-jones-jr-at-the-dubrovnik-three-seas-initiative-presidential-roundtable (accessed: 6.09.2018).

Sienkiewicz, M., Koncepcja Trójmorza w polityce zagranicznej Polski po 2015 r. [The Three Seas idea in the Polish foreign policy after 2015] (in Polish), "Dyplomacja i Bezpieczeństwo" [Diplomacy and Security], No. 1, 2016. Available at: http://www.repozytorium.uni.wroc.pl/Content/79656/Sienkiewicz_M_DiB-2016.pdf (accessed: 26.09. 2018).

The emergence of a European Project. Three Summits for the Three Seas Initiative, 'New Strategy Center, Ośrodek Studiów Wschodnich', Warszawa, 2018, p. 4. Available at: https://newstrategy center.ro/wp-content/uploads/2016/04/NSC_OSW_3SI_ policy_paper.pdf (accessed: 6.09.2018).

The Joint Declaration of the Third Summit of the Three Seas Initiative. Available at: http://www.presidency.ro/ro/media/comunicate-de-presa/joint-declaration-of-the-third-summit-of-the-three-seas-initiative (accessed: 26.09.2018).

The joint report by the Atlantic Council and Central Europe Energy Partners in coordination with the Central \& Eastern Europe Development Institute with the support of Grupa LOTOS S.A. and Przedsiębiorstwo Eksploatacji Rurociągów Naftowych S.A., PERN Przyjaźń. Available at: http://www.ceep.be/www/wp-content/uploads/2015/03/Europe-needs-an-energy-highway_PR_CEEP.pdf (accessed: 6.09.2018).

The Joint Statement for the creation of the network of the Chambers of Commerce of the "Three Seas Initiative". Available at: http://www.presidency.ro/ro/media/comunicate-de-presa/joint-statement-for-the-creation-of-the-network-of-the-chambers-of-commerce-of-the-three-seas-initiative (accessed: 26.09. 2018).

The Joint Statement on the Three Seas Initiative (the Dubrovnik Statement). Available at: http://predsjednica.hr/files/The\%20Joint\%20Statement\%20on\%20The\%20 Three\%20Seas\%20Initiative(1).pdf (accessed: 6.09.2018).

The official Eurostat database. Available at: https://ec.europa.eu/eurostat/data/database (accessed: 6.09.2018).

The official website of U.S. Diplomatic Mission to Germany, A Europe Whole and Free. Available at: https://usa.usembassy.de/etexts/ga6-890531.htm (accessed: 9.09.2018). 
The official website of the Whitehouse, Remarks by President Trump to the People of Poland, issued on 6.07.2017. Available at: https://www.whitehouse.gov/briefings-statements/remarks-president-trump-people-poland/ (accessed: 9.09.2018).

The official website of the Three Seas Initiative Bucharest Summit, Q\&A. Available at: http://three-seas.eu/qa/ (accessed: 12.09.2018).

The Second Summit of the 3 Seas Initiative Joint Declaration. Available at: http:// three-seas.eu/wp-content/uploads/2018/06/WARSAW.pdf (accessed: 11.09.2018).

The Three Seas Initiative - Priority Interconnection Projects. Available at: http:// three-seas.eu/press-releases/ (accessed: 26.09.2018).

Ukielski, P., Mapa Trójmorza. Przegląd punktów wspólnych i rozbieżności w polityce 12 państw regionu [The Three Seas Map. A review of convergences and divergences] (in Polish), Report No. 3/2016, Centrum Analiz Klubu Jagiellonśkiego [Jagiellonian Club Analysis Centre]. Available at: http://cakj.pl/wp-content/uploads/2016/11/ Raport-3-2016.pdf (accessed: 26.09.2018).

Wiśniewski, B. (2017), Trójmorze - nowy instrument w polskiej polityce zagranicznej [Three Seas Initiative - new tool of the Polish foreign politics] (in Polish), "Polski Przegląd Dyplomatyczny", Polski Instytut Spraw Międzynarodowych [The Polish Diplomatic Review of the Polish Institute of International Affairs], No. 4 (71) 2017.

\section{Streszczenie}

\section{Inicjatywa Trójmorza i jej gosporadczy i geopolityczny wpływ na UE oraz kraje Europy Środkowo-Wschodniej}

Celem artykułu jest przedstawienie wyników analizy Inicjatywy Trójmorza, którą kraje je tworzące (z wyjątkiem Austii) traktują jako metodę na: a) zmniejszenie uzależnienia energetycznego w zakresie importu ropy i gazu z Rosji, b) szybsze nadrobienie nadal istniejących różnic cywilizacyjnych względem bardziej rozwiniętych krajów EU dzięki poprawieniu jakości i rozwoju infrastruktury transportowej i cyfrowej z Północy na Południe, c) realnemu urzeczywistnieniu „wizji całej, wolnej i pokojowej Europy”. W analizie przyjęto następującą tezę badawczą: Przystąpienie krajów ESW do UE nie przyczyniło się w istotny sposób do zmiany ich statusu rozwojowego, ponieważ w dalszym ciągu istnieją znaczące różnice w poziomie rozwoju pomiędzy krajami nowej i starej Unii, która została zweryfikowana pozytywnie.

Słowa kluczowe: Unia Europejska, inicjatywa Trójmorza, bezpieczeństwo energetyczne, kraje Europy Środkowo-Wschodniej, geopolityka 